\title{
Phytoremediation and Plant-Assisted Bioremediation in Soil and Treatment Wetlands: A Review
}

\author{
Jaak Truu ${ }^{\mathrm{ab},{ }^{*}}$, Marika Truu ${ }^{\mathrm{a}}$, Mikk Espenberg $^{\mathrm{a}}$, Hiie Nõlvak ${ }^{\mathrm{a}}$, Jaanis Juhanson ${ }^{\mathrm{c}}$ \\ ${ }^{a}$ Institute of Ecology and Earth Sciences, University of Tartu, 46 Vanemuise Street, Tartu 51014, Estonia \\ ${ }^{b}$ Faculty of Geography and Earth Sciences, University of Latvia, Alberta Street 10, Riga, LV-1010, Latvia \\ ${ }^{c}$ Department of Microbiology, Swedish University of Agricultural Sciences, 75007 Uppsala, Sweden
}

\begin{abstract}
Phytoremediation is a technology that is based on the combined action of plants and their associated microbial communities to degrade, remove, transform, or immobilize toxic compounds located in soils, sediments, and more recently in polluted ground water and wastewater in treatment wetlands. Phytoremediation could be used to treat different types of contaminants including petroleum hydrocarbons, chlorinated solvents, pesticides, explosives, heavy metals and radionuclides in soil and water. The advantages of phytoremediation compared to conventional techniques are lower cost, low disruptiveness to the environment, public acceptance, and potentiality to remediate various pollutants. The use of plants in conjunction with plant associated bacteria (rhizosphere or endophytic) offers greater potential for bioremediation of organic compounds, and in some cases inorganic pollutants than using plants alone in bioremediation. The implementation of treatment wetlands for phytoremediation of wastewater or polluted water originating from various sources allows removing organic and inorganic pollutants from water in an environmentally friendly and economically feasible way.

Presently, different processes of phytoremediation in treatment wetlands are less studied compared to phytoremediation of polluted soils. Further research is needed to advance the understanding of the pollutant removal mechanisms in treatment wetlands with vegetation, and how based on this information to improve treatment wetland design and operational parameters to achieve more efficient treatment processes. This review covers basic processes of phytoremediation with special emphasis on rhizoremediation and plant-microbe interactions in plant-assisted biodegradation in soil and treatment wetlands.
\end{abstract}

Keywords: Rhizoremediation, phytoremediation, treatment wetlands.

\section{INTRODUCTION}

An increasingly industrialized global economy has led to dramatically elevated releases of anthropogenic chemicals into the environment over the last century and resulted in contamination of many areas on Earth. Contamination can be a result of improper chemical production (i.e. oil spills from drilling, explosives from manufacturing), transport (i.e. oil spills from tankers or pipelines), storage (i.e. chemicals from leaking storage tanks), usage (i.e. pesticides and fertilizers from agriculture, explosives from munitions firing) or disposal processes (i.e. explosives from demilitarization facilities).

Concurrently with increasing pollution levels, avid interest in developing strategies for remediation of environmental contaminants using physical, chemical and biological processes has emerged. As classic "suck and truck" strategies followed by off-site treatments are expensive, the in situ bioremediation processes like monitored

*Address correspondence to these authors at the Institute of Ecology and Earth Sciences, University of Tartu, 46 Vanemuise Street, Tartu 51014, Estonia; Tel: +372 7737 6843; E-mail: jaak.truu@ut.ee natural attenuation (MNA), biostimulation, bio-augmentation and phytoremediation (incl. rhizoremediation) have become an attractive way to rehabilitate contaminated sites [1]. Besides the aforementioned methods, a variety of other remediation technologies are available for on-site remediation of polluted soils. Soil vapour extraction, landfarming, bioventing, thermal desorption, and biopiles have been used as real life applications for on-site soil cleanup [2]. However, no single technology is appropriate for all contaminant types and the variety of site-specific conditions which exist at different contaminated sites and often more than one remediation technology is needed to effectively address contaminated site problems [2]. Site conditions, contaminant type and source, source control measures, and the potential impact of the possible remedial measure determine the choice of a remediation strategy and technology. In recent decades, phytoremediation - a cost effective and environmentally friendly technology - has been used successfully for the remediation of soils contaminated with various pollutants. In addition, phytoremediation is increasingly used as a technological complement for treatment of polluted water in different types of treatment wetlands $[3,4]$. However, compared to phytoremediation of 
the polluted soils the plant application in treatment wetlands for pollutant removal have been mostly studied as a ,black box" (ie the main assessed parameter is pollutant removal efficiency), and there is very limited information available about of the pollutant removal mechanisms and process dynamics in these systems.

The aim of this paper is to briefly review basic processes of phytoremediation with special emphasis on rhizoremediation and plant-microbe interactions in plant-assisted biotransformation of organic and inorganic pollutants in soil. In addition, the potential and challenges of phytoremediation strategy for enhanced removal of organic and inorganic pollutants from water in treatment wetlands are addressed.

\section{PHYTOREMEDIATION PROCESSES}

According to Cunningham and Berti phytoremediation is defined as the use of green plants to remove, contain, or render harmless environmental contaminants [5]. In this process specially selected or genetically engineered plants are used which are capable of direct uptake of pollutants from the environment [6]. Phytoremediation can be applied to both inorganic and organic pollutants present in solid and liquid substrate [7]. Generally, phytoremediation of contaminants by a plant involves the following steps: uptake, translocation, transformation, compartmentalization, and sometimes mineralization [8]. Factors affecting the uptake, distribution and transformation of organic compounds by a plant are mainly related to the physical and chemical properties of the compound (e.g. water solubility, molecular weight, octanol-water partition coefficient), as well as environmental conditions (e.g. temperature, $\mathrm{pH}$, organic matter, and soil moisture content) and plant characteristics (e.g. root system, enzymes) [9, 10]. Although the designations of different phytoremediation strategies vary in literature, the principal scheme is given in Fig. (1).

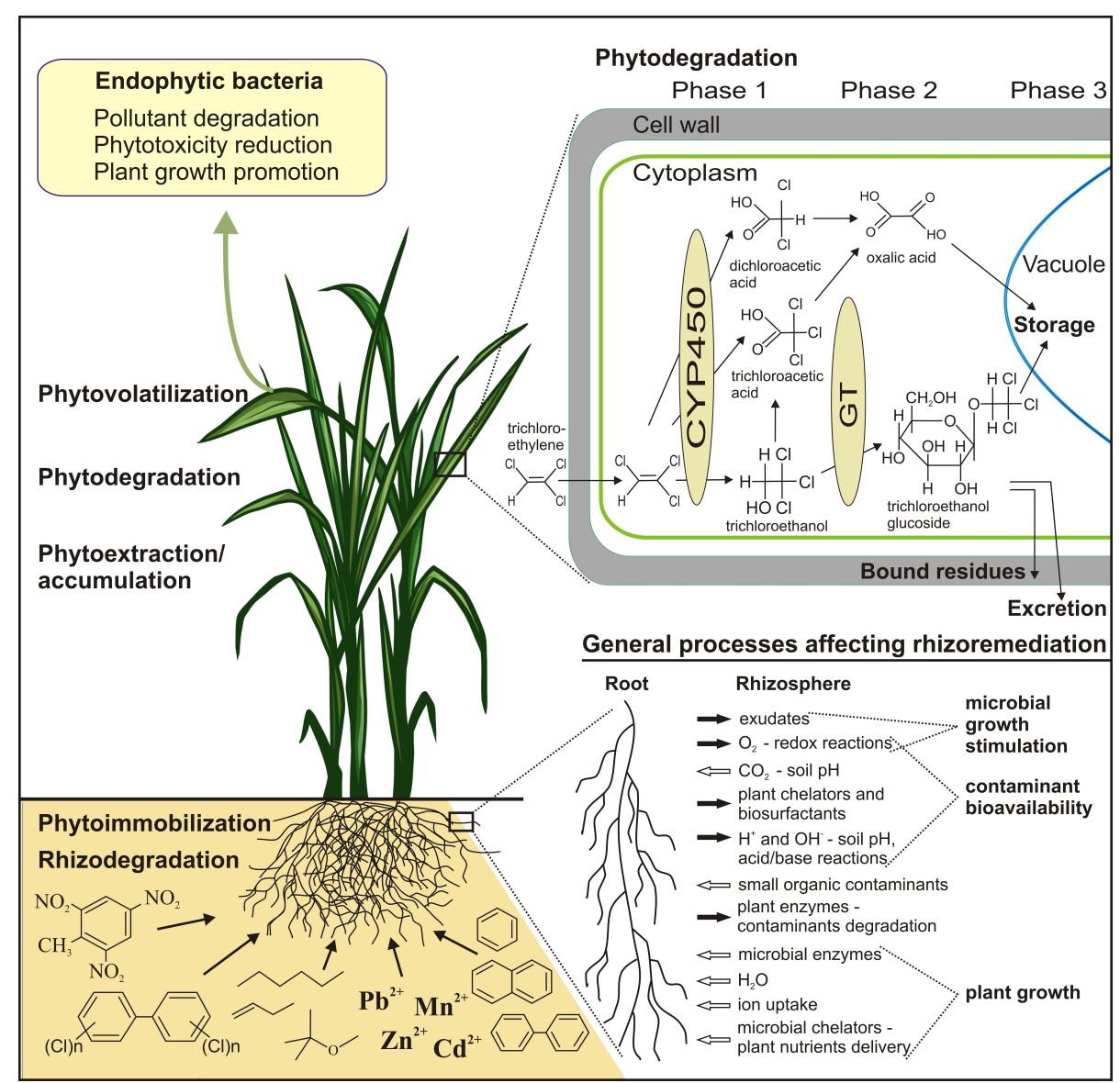

Fig. (1). Phytoremediation of various organic and inorganic pollutants in soil. Plants are capable of removing organic and inorganic contaminants from soil by roots (phytoimmobilization), but also transporting and concentrating them in the harvestable part of the plant (phytoextraction/accumulation). In some cases transpiration to the atmosphere through leaf stomata may follow (phytovolatilization). Organic contaminants can be metabolized inside the plant (phytodegradation) in three sequential steps (phase 1 - transformation, phase 2 conjugation, phase 3 - compartmentalization) using enzymes, such as CYP450 - cytochrome P450; GT - glycosyltransferase, resulting in the storage of the contaminant in the vacuole, integration into the cell wall, or excretion from the cell. In addition, organic contaminants can be degraded by plant-associated microorganisms in the rhizosphere (rhizodegradation). Plants facilitate the biodegradation of contaminants by releasing root exudates and other compounds to the surrounding soil as well as providing surface for the colonization of microbes, contributing in this way to the increased number and metabolic activity of microorganisms (rhizosphere effect) and enhanced bioavailability of the contaminant. Plants provide nutrients for endophytic bacteria and induce catabolic gene expression. Endophytic bacteria degrade organic pollutants reducing in this way phytotoxicity, and produce plant growth promoting hormones. 
Inorganic contaminants (heavy metals and radionuclides) can be either taken up from the soil and immobilized by the roots (phytoimmobilization), or transported to the plant shoot (phytoextraction) [11]. Since under most circumstances the bioavailability of metals (including some metals essential to life) in soil is rather low, plants possess highly effective metal uptake systems using transporter molecules such as zinc-regulated transporter protein, copper transporter protein etc. [12]. In addition, plants are capable of secreting metalchelating molecules like siderophores and organic acids (malate, citrate), and biosurfactants such as rhamnolipids to the surrounding soil, and also extruding protons from the roots to acidify the soil and mobilize soil bound metals (Fig. 1) $[13,14]$. Contrary to organic pollutants heavy metals cannot be biodegraded inside the plant but are only transformed from one oxidation state or organic complex to another [14]. As a result, metals tend to accumulate in the plant. Nearly 450 hyperaccumulator plants ranging from annual herbs to perennial shrubs and trees (e.g. tobacco, sunflower, mustard, maize, pennycress, brake fern, Russian thistle, rattlebush, python tree, willow, poplar) have been described to accumulate and detoxify extraordinary high levels of metal ions, such as $\mathrm{Ni}, \mathrm{Co}, \mathrm{Pb}, \mathrm{Zn}, \mathrm{Mn}, \mathrm{Cd}$, etc. in their above ground tissues [15-18]. It has been suggested, that the prevention of herbivory and disease may be the main function of hyperaccumulation for the plant [17, 19]. Still, in this case it is possible to harvest and remove plants from the site after remediation for disposal or recovery of the contaminants [10]. For some inorganic elements $(\mathrm{Hg}, \mathrm{As}, \mathrm{Se})$ uptake by roots followed by transport to the shoot and transpiration to the atmosphere through the leaf stomata (phytovolatilization) have been observed [16, 20]. Since the volatile forms of $\mathrm{Hg}$ and $\mathrm{Se}$ are also toxic, it is questionable whether the volatilization of these elements into the atmosphere is desirable or safe $[16,21]$.

Organic pollutants in soil like chlorinated solvents and polyaromatic hydrocarbons (PAHs) can be taken up and immobilized by plant roots [22] as well as transpired from the shoot (methyl tert-butyl ether - MTBE, trichloroethylene - TCE, ethyl-benzene, xylene) [23, 24]. In addition, contrary to inorganic pollutants plants are capable of metabolizing organic contaminants (phytodegradation). The metabolism of contaminants by a plant can be divided into three phases: transformation, conjugation and compartmentalization (Fig. 1). In the transformation phase, contaminant is chemically modified (oxidation, reduction, and hydrolysis) and transformed into more polar, water soluble form by enzymes such as cytochrome P450 or carboxylesterases. By conjugation with endogenous molecules like sugars or peptides, the transformed contaminant is made less phytotoxic by glycosyltransferases and glutathione Stransferases, followed by compartmentalization phase where contaminant is transferred to the various compartments of the cell (storage in the vacuole or integration into cell wall) or in some cases excreted from the cell [11, 23, 25]. However, there is a principle difference between metabolism of contaminants by a plant and by microorganisms - most contaminants are not utilized as a source of $\mathrm{C}, \mathrm{N}$ and energy by plant since plants do not possess complete catabolic pathways for degradation and mineralization of pollutants $[25,26]$. During the degradation process even more toxic by- products (from the human point of view) may be produced compared to the initial pollutant. For instance, the transformation of TCE into trichloroethane, or the release of some metabolites from volatile pollutants into the environment by evapotranspiration have been detected [23, 27]. Only a few types of contaminants, for example polychlorinated biphenyls (PCBs), PAHs, nitroaromatics and linear halogenated hydrocarbons can be completely mineralized by plants such as poplar, willow, alfalfa and different grass varieties [15, 28].

Transgenic plants can be developed by transferring genes from organisms which have the potential for degradation/ mineralization of xenobiotic pollutants to candidate plants to improve the ability of plants to degrade/metabolize xenobiotic pollutants. Genes involved in the degradation of xenobiotic pollutants can be isolated from bacteria/fungi/ animals/plants and introduced into candidate plants using Agrobacterium mediated or direct DNA methods of gene transfer [25]. Specific catabolic genes essential for the degradation of a contaminant are overexpressed in a plant, resulting in enhanced phytoremediation. For example, transgenic tobacco, rockcress, mustard, poplar, rice, potato have been reported to be able to improve phytoextraction, phytovolatilization and phytodegradation of heavy metals and organic contaminants like explosives, chlorinated solvents, PAHs, polychlorinated biphenyls, various herbicides, and atrazine [25, 29-31]. The most recent and very promising approach to improve phytoremediation ability is the construction of plants with enhanced secretion of enzymes capable of degrading xenobiotics into the rhizosphere [32, 33]. The advantage of this method is that the plants do not need to take up the pollutants in order to detoxify them; instead, the secreted enzymes can degrade the pollutants in the rhizospheric zone [34]. However, there are strict regulatory restrictions for in situ applications of genetically modified organisms in the European Union and promising results have been obtained only in the laboratory and greenhouse experiments.

\section{RHIZOREMEDIATION AND MICROBE-PLANT INTERACTIONS IN PHYTOREMEDIATION}

Rhizoremediation (also rhizodegradation, microbeassisted phytoremediation, rhizosphere bioremediation) utilizes the complex interactions involving roots, root exudates, rhizosphere soil and microbes that result in degradation of contaminants to non-toxic/less-toxic compounds. Plant roots stimulate rhizosphere microbial communities by aerating the soil and releasing exoenzymes as well as nutrients through root exudates while also providing surface for colonization and niches to protect bacteria against desiccation and other abiotic and biotic stresses [28]. Rhizospheric microorganisms in turn promote the plant growth by nitrogen fixation, nutrient (i.e. phosphorus) mobilization, production of plant growth regulators, decreasing plant stress hormone levels, providing protection against plant pathogens and degradation of pollutants before they negatively impact the plant (Fig. 1) $[35,36]$. Consequently these mutual interactions, also known as rhizosphere effect, result in elevated number, diversity and metabolic activity of microbes able to degrade contaminants or support plant growth in close vicinity of 
roots compared to bulk soil [37, 38]. In many cases, rhizosphere microbes are the main contributors to the contaminant degradation process.

The amount and composition of root exudates which create nutrient rich environment in the vicinity of roots is specific to plant family or species. Root exudates contain organic acids (lactate, acetate, oxalate, succinate, fumarate, malate, and citrate), sugars and amino acids as main components but also secondary metabolites (isoprenoids, alkaloids, and flavonoids) which are released to the soil as rhizodeposits [39-41]. The main fraction of exuded organic acids are present in soil as dissociated anions (carboxylates) [42]. It has been suggested that $10-44 \%$ of the photosynthetically fixed carbon is excreted by rhizodeposition [43, 44]. Root exudates can be used as an energy source by microorganisms. In addition, the structure of many secondary metabolites resembles those of contaminants thus inducing the expression of specific catabolic genes in microorganisms necessary for the degradation of the contaminant [40]. For instance, plant secondary metabolite salicylate has been linked to the microbial degradation of PAHs (naphthalene, fluoranthene, pyrene, chrysene) and PCB [45-47], while terpenes can induce the microbial degradation of toluene, phenol, and TCE [48]. Easily degradable root-exuded compounds can also serve as co-metabolites in processes where contaminants cannot be used as a sole carbon source (i.e. aerobic degradation of trichloroethylene [49] due to negative energy balance) [11]. This is important under many circumstances where microorganisms cannot rely on energy gain from the contaminant and cometabolism is the only route for the degradation of contaminant. Plant roots along with some rhizospheric bacteria may also excrete biosurfactants thus increasing the bioavailability and uptake of pollutants [28, $50,51]$. This aspect can be especially beneficial in aged soils with low contaminant bioavailability that generally appear to be much less responsive to rhizodegradation than freshly spiked soil [52, 53].

A recent strategy to improve phytoremediation and detoxification of contaminants is the use of endophytic bacteria. Endophytic bacteria are described as nonpathogenic bacteria and they seem to have a ubiquitous existence in most if not all higher plant species. They often belong to genera commonly found in soil, including Pseudomonas, Burkholderia, Bacillus and Azospirillum [5456]. Endophytic bacteria are also known to have plant growth promoting and pathogen control capabilities $[57,58]$. A major advantage of using endophytic bacteria over rhizospheric bacteria in phytoremediation is that while a rhizospheric bacterial population is difficult to control, and competition between rhizospheric bacterial strains often reduces the number of the desired strains (unless metabolism of the pollutant is selective), the use of endophytes that naturally inhabit the internal tissues of plants reduces the problem of competition between bacterial strains $[59,60]$. Studies suggest that these bacteria can be used to complement the metabolic potential of their host plant through direct degradation [61-64] as well as transfer of degradative plasmids to other endophytes $[65,66]$. In addition to pollutant degradation pathway endophytic bacteria may also possess the capability to enhance plant growth and adaption by 1-aminocyclopropane-1-carboxylate (ACC)-deaminase activity, siderophore production and nutrient solubilization. Presence of such bacteria in plants leads to more efficient phytoremediation activity, and reduces need for additional fertilization [67].

Even enhanced rhizoremediation might be considerably slower than ex situ treatments due to environmental restrictors at field sites such as competition by weed species which are better adapted to the site [68], limited plant growth in heavily and unevenly contaminated soil, presence of plant pathogens and other biotic and abiotic stressors [33]. Furthermore, rhizoremediation is effective only in rooting zone and is unsuitable for usage in deeper subsurface layers. Some toxic contaminant metabolites can also bioaccumulate in plants making strict regulations of plant material treatment necessary. However, despite the aforementioned shortcomings rhizoremediation is emerging as one of the most effective means by which plants can affect the remediation of organic contaminants, particularly large recalcitrant compounds $[11,33,42,69]$. Besides its relatively low maintenance costs, no size restrictions for the area and environmentally friendly nature, the quality and texture of soil is also improved by additions of organic materials, nutrients and oxygen via plant and microbial metabolic processes. Despite the challenges of introducing phytoremediation from lab and greenhouse scale to field, rhizoremediation has been used to treat field sites contaminated with petroleum hydrocarbons $[68,70]$, PAHs [71, 72], TNT [73], BTEX [74] and TCE [75, 76]. To date, many successful cases of phytoremediation of various organic contaminants using rhizospheric or endophytic bacteria have been reported (Supplementary Table 1).

Likewise to other bioremediation techniques detailed and continuous monitoring of chemical and biological indicators is essential to ensure phytoremediation process efficiency and environmental safety.

\section{APPLICATION OF PHYTOREMEDIATION IN TREATMENT WETLANDS}

Treatment wetlands (also known as constructed wetlands) are effective and low-cost operational alternatives to conventional technologies for the elimination of a wide range of contaminants from wastewaters and polluted groundwater [77-80]. Generally treatment wetlands have been applied to treat municipal or industrial wastewater [81], and more recently for the removal of excessive nitrogen and phosphorous from polluted surface and subsurface waters to protect aquatic ecosystems [82, 83]. An integration of phytoremediation has been suggested to improve the performance of existing wastewater treatment in constructed wetlands, especially towards the emerging micropollutants, i.e. organic chemicals, personal care products and pharmaceuticals (incl. antibiotics) [84, 85]. However, the biogeochemical processes associated with the transformation of the organic chemicals in vegetated treatment wetlands are so far rarely evaluated probably owing to the complex and synergistic nature of ongoing processes. In a complex treatment wetland system several elimination pathways of organic compounds (volatilization, photochemical oxidation, sedimentation, sorption, and biodegradation) may occur 
simultaneously while plants may contribute either by direct contaminant uptake and accumulation, phytovolatilization, and metabolic transformation, or by creating conditions favourable for pollutant removal within the treatment systems [86]. The latter involves acting as suitable surface for biofilm anchorage, promoting the development and growth of different microbial species within the systems by secreting root exudates, pumping and releasing oxygen to the deeper layers of the wetland media, retaining suspended solids particles and insulating against low temperature [87]. The relative importance of a particular process varies, depending on the organic or inorganic contaminant to be treated, the treatment wetland type (free-water, subsurface flow, horizontal flow or vertical flow, type of vegetation) and operational design (wastewater loading rate and retention time, soil matrix type). Zhang and co-workers analysed how much different processes such as microbial degradation, photodegradation and plant uptake contribute to the removal of pharmaceutical compounds from wastewater in aquatic plant-based systems [88]. They found that plant uptake played the dominant role in elimination of clofibric acid and caffeine, and was also significant in the case of ibuprofen. However, the impact of the plants presence and the ability of particular species to improve the removal efficiency of certain pharmaceutical compounds and personal care products still remains unclear. This is because many other factors, like the structure of rhizosphere microbial communities and the properties of the wastewater, as well as environmental (temperature, availability of electron acceptors) and operational conditions (hydraulic retention time, specific surface area, loading mode) may all act in concert $[89,90]$. For example in case of surface flow constructed wetland planted and unplanted mesocosms were not significantly different in their abilities to remove pharmaceuticals [91].

Besides their role in wastewater treatment, macrophytes also have the ability to mitigate pesticide pollution arising from various agricultural non-point sources in treatment wetlands [92, 93]. For instance, wetland treatment of water contaminated with low chlorinated benzenes has been investigated in several studies $[94,95]$ and it has been shown that although the uptake of this compound by plants was $<0.1 \%$ of the initial concentration, the mean removal of hexachlorobenzene (HCB) was higher in the vegetated microcosm wetlands [96]. Furthermore, the dechlorination rates of $\mathrm{HCB}$ were found to be higher in sediment layers with well-developed root zones [97]. In case of herbicide Smetolachlor the removal efficiency have been found to be dependent on hydraulic regime in planted subsurface flow constructed wetland being substantially lower in continuous flow operation mode compared to batch mode [98]. The batch operation strategy also improved the removal efficiency of ibuprofen, diclofenac, oxybenzone, caffeine, salicylic acid, ketoprofen and bisphenol $\mathrm{A}$ in planted horizontal flow constructed wetland systems [99, 100].

Vegetated treatment wetlands also offer a promising way to remediate water contaminated with inorganic compounds like metals and metalloids with metal uptake by various macrophytes being the prominent pollutant removal mechanism. For instance, common reed (Phragmites australis) has a potential to extract and accumulate chromium from tannery wastewater [101, 102] while broadleaved cattail (Typha latifolia) has been established as a prominent copper and cadmium remover from industrial wastewater in a lab-scale experiment [103]. In another labscale study heavy metal (Cd (II), $\mathrm{Hg}$ (II), $\mathrm{Cr}$ (VI) and $\mathrm{Pb}$ (II)) removal from a synthetic landfill leachate ranged from 92 to $98 \%$ in all reactors planted with wild cane (Gynerium sagittatum), taro (Colocasia esculenta) and Parrot's flower (Heliconia psittacorum) [104]. Good pollutant removal efficiencies achieved in lab-scale do not always guarantee treatment process success in larger/field scale; still, a few successful phytoremediation treatment trials of inorganic contaminants in constructed wetlands have been reported. A pilot-scale study in a subsurface flow treatment wetland showed a great potential of the aquatic macrophyte southern cattail (Typha domingensis) for the phytoremediation of water contaminated with mercury. Also, in a study by Anning and co-workers the removal efficiencies for different heavy metals from a contaminated river water varied $(\sim 20$ $77 \%)$ in a planted treatment wetland system [105]. The removal of heavy metals in treatment wetlands could be enhanced by supplementing treatment systems with siderophore-producing bacteria as shown in a study where repeated bioaugmentation increased the amount of $\mathrm{Cu}$ extracted by common reed (Phragmites australis) twice due to the increased $\mathrm{Cu}$ bioaccessibility in the rhizosphere [106].

\section{CONCLUSIONS AND OUTLOOK}

Phytoremediation is a technology that is based on the combined action of plants and their associated microbial communities to degrade, remove, transform, or immobilize toxic compounds located in soils, sediments, ground water and surface water. Phytoremediation has been used to treat many classes of contaminants including petroleum hydrocarbons, chlorinated solvents, pesticides, explosives, heavy metals and radionuclides in soil and polluted water. There are several advantages of phytoremediation compared to conventional techniques, such as low cost, low disruptiveness to the environment, public acceptance, and potentiality to remediate various pollutants. In addition, plants as autotrophic systems with large biomass require only a modest nutrient input, and they also prevent the spread of contaminants through water and wind erosion [29]. Candidate plant for phytoremediation should have the characteristics such as high biomass production, extensive root system, and ability to tolerate high concentration of pollutants and withstand environmental stress. Like other treatment technologies, phytoremediation has its disadvantages e.g. climatic and geological limitations, potential phytotoxicity of the contaminant, potential for the contaminant or its metabolites to enter the food chain, and potentially longer timescale compared to other technologies [6]. Although some success has been reported using plants alone in bioremediation, the use of plants in conjunction with plant associated (rhizosphere or endophytic) bacteria offers more potential for bioremediation. The implementation of treatment wetlands for phytoremediation of wastewater or polluted water originating from various sources allows removing organic and inorganic pollutants from water in an environmentally friendly and economically feasible way. Treatment wetlands utilizing phytoremediation approach 
could be combined with existing treatment systems, or the complex treatment wetland systems could be designed according to the site-specific requirements. However, compared to phytoremediation of polluted soils the mode of action and technological aspects of the plant application for the pollutants removal in treatment wetlands is less studied, especially in case of inorganic compounds and micropollutants (pharmaceutical compounds and personal care products). Also, the possible release of pollutant transformation products and unknown derivatives from treatment wetlands into environment has to be taken into account. Further research is needed in order to understand the plant-microbe interactions during removal of contaminants including micropollutants in different types of treatment wetlands. Based on this knowledge treatment wetland design and operational parameters could be improved to achieve more efficient pollutant removal efficiency.

\section{CONFLICT OF INTEREST}

The authors confirm that no conflicts of interest are associated with this article.

\section{ACKNOWLEDGMENTS}

The study was financially supported by ESF project 2013/0020/1DP/1.1.1.2.0./13/APIA/VIAA/066, Interdisciplinary Team of Young Scientists for Assessment and Restoration of Soil Quality and Usage Potential in Latvia", and by the Ministry of Education and Research of the Republic of Estonia (grants IUT2-16 and 3.2.0801.11-0026), and by the European Regional Development Fund through ENVIRON (Centre of Excellence in Environmental Adaptation).

\section{SUPPORTIVE/SUPPLEMENTARY MATERIAL}

Supplementary Table 1. Examples of successful phytoremediation cases of various organic contaminants using rhizospheric bacteria $(\mathrm{RH})$ or endophytic bacteria $(\mathrm{EN})$.

\section{REFERENCES}

[1] Ayoub K, van Hullebusch ED, Cassir M, Bermond A. Application of advanced oxidation processes for TNT removal: A review. J Hazard Mater 2010; 178(1-3): 10-28.

[2] Khan FI, Husain T, Hejazi R. An overview and analysis of site remediation technologies. J Environ Manage 2004; 71: 95-122.

[3] Horne A. Phytoremediation by constructed wetlands. In: Terry N, Banuelos GS, Eds. Phytoremediation of Contaminated Soil and Water. CRC Press; Florida 1999; pp. 13-40.

[4] Zhang BY, Zheng JS, Sharp RG. Phytoremediation in engineered wetlands: Mechanisms and applications. Proc Environ Sci 2010; 2: pp. 1315-25.

[5] Cunningham SD, Berti WR. Remediation of contaminated soils with green plants: An overview. In Vitro Cell Dev Biol 1993; 29: 207-12.

[6] Macek T, Mackova M, Kas J. Exploitation of plants for the removal of organics in environmental remediation. Biotechnol Adv 2000; 18: 23-34.

[7] Salt DE, Smith RD, Raskin I. Phytoremediation. Ann Rev Plant Physiol Plant Mol Biol 1998; 49: 643-68.

[8] Schnoor JL, Licht LA, McCutcheon SC, Wolfe NL, Carreira LH. Phytoremediation of organic and nutrient contaminants. Environ Sci Technol 1995; 29: 318-23.
[9] Suresh B, Ravishankar GA. Phytoremediation - a novel and promising approach for environmental clean-up. Crit Rev Biotechnol 2004; 24: 97-124.

[10] Susarla S, Medina VF, McCutcheon SC. Phytoremediation: An ecological solution to organic chemical contamination. Ecol Eng 2002; 18: 647-58.

[11] Reichenauer TG, Germida JJ. Phytoremediation of organic contaminants in soil and groundwater. ChemSusChem 2008; 1: 708-17.

[12] Krämer U, Talke IN, Hanikenne M. Transition metal transport. FEBS Lett 2007; 581: 2263-72.

[13] Eapen S, D'Souza SF. Prospects of genetic engineering of plants for phytoremediation of toxic metals. Biotechnol Adv 2005; 23: 97114.

[14] Garbisu C, Alkorta I. Phytoextraction: A cost-effective plant-based technology for the removal of metals from the environment. Bioresour Technol 2001; 77: 229-36.

[15] Meagher RB. Phytoremediation of toxic elemental and organic pollutants. Curr Opin Plant Biol 2000; 3: 153-62.

[16] Padmavathiamma PK, Li LY. Phytoremediation technology: Hyper-accumulation metals in plants. Water Air Soil Pollut 2007; 184: $105-26$.

[17] Shah K, Nongkynrih JM. Metal hyperaccumulation and bioremediation. Biol Plant 2007; 51: 618-34.

[18] Sheoran V, Sheoran AS, Poonia P. Phytomining: A review. Miner Eng 2009; 22: 1007-19.

[19] Fattorini D, Notti A, Nigro M, Regoli F. Hyperaccumulation of vanadium in the Antarctic polychaete Perkinsiana littoralis as a natural chemical defense against predation. Environ Sci Pollut Res 2010; 17: 220-8.

[20] Pilon-Smits E. Phytoremediation. Annu Rev Plant Biol 2005; 56: 15-39.

[21] Watanabe ME. Phytoremediation on the brink of commercialization. Environ Sci Technol 1997; 31: 182-6.

[22] Gao Y, Zhu L. Plant uptake, accumulation and translocation of phenanthrene and pyrene in soils. Chemosphere 2004; 55: 1169-78.

[23] Ma X, Burken JG. TCE diffusion to the atmosphere in phytoremediation applications. Environ Sci Technol 2003; 37: 2534-9.

[24] Ma X, Richter AR, Albers S, Burken JG. Phytoremediation of MTBE with hybrid poplar trees. Int J Phytoremediat 2004; 6: 15767.

[25] Eapen S, Singh S, D'Souza SF. Advances in development of transgenic plants for remediation of xenobiotic pollutants. Biotechnol Adv 2007; 25: 442-51.

[26] Schröder P, Collins C. Conjugating enzymes involved in xenobiotic metabolism of organic xenobiotics in plants. Int J Phytoremediat 2002; 4: 247-65.

[27] Burken JG, Schnoor JL. Predictive relationships for uptake of organic contaminants by hybrid poplar trees. Environ Sci Technol 1998; 32: 3379-85.

[28] Kuiper I, Lagendijk EL, Bloemberg GV, Lugtenberg BJ. Rhizoremediation: A beneficial plant-microbe interaction. Mol Plant Microbe Interact 2004; 17: 6-15.

[29] Cherian S, Oliveira MM. Transgenic plants in phytoremediation: Recent advances and new possibilities. Environ Sci Technol 2005; 39: 9377-90.

[30] Rylott EL, Bruce NC. Plants disarm soil: Engineering plants for the phytoremediation of explosives. Trends Biotechnol 2009; 27: 7381.

[31] Panz K, Miksch, K. Phytoremediation of explosives (TNT, RDX, HMX) by wild-type and transgenic plants. J Environ Manage 2012; 113: 85-92.

[32] Abhilash PC, Jamil S, Singh N. Transgenic plants for enhanced biodegradation and phytoremediation of organic xenobiotics. Biotechnol Adv 2009; 27: 474-88.

[33] Gerhardt KE, Huang XD, Glick BR, Greenberg BM. Phytoremediation and rhizoremediation of organic soil contaminants: Potential and challenges. Plant Sci 2009; 176: 20-30.

[34] Kawahigashi H. Transgenic plants for phytoremediation of herbicides. Curr Opin Biotechnol 2009; 20: 225-30.

[35] Chaudhry Q, Blom-Zandstra M, Gupta S, Joner EJ. Utilising the synergy between plants and rhizosphere microorganisms to enhance breakdown of organic pollutants in the environment. Environ Sci Pollut R 2005; 12(1): 34-48. 
[36] Segura A, Rodríguez-Conde S, Ramos C, Ramos JL. Bacterial responses and interactions with plants during rhizoremediation. Microb Biotechnol 2009; 2(4): 452-64.

[37] Ramos C, Mølbak L, Molin S. Bacterial activity in the rhizosphere analyzed at the single-cell level by monitoring ribosome contents and synthesis rates. Appl Environ Microb 2000; 66(2): 801-9.

[38] Kent AD, Triplett EW. Microbial communities and their interactions in soil and rhizosphere ecosystems. Annu Rev Microbiol 2002; 56: 211-36.

[39] Jones DL. Organic acids in the rhizosphere - a critical review. Plant Soil 1998; 205: 25-44.

[40] Singer AC, Crowley DE, Thompson IP. Secondary plant metabolites in phytoremediation and biotransformation. Trends Biotechnol 2003; 21: 123-30.

[41] Singh BK, Millard P, Whiteley AS, Murrell JC. Unravelling rhizosphere-microbial interactions: Opportunities and limitations. Trends Microbiol 2004; 12: 386-93.

[42] Martin BC, George SJ, Price CA, Ryan MH, Tibbett M. The role of root exuded low molecular weight organic anions in facilitating petroleum hydrocarbon degradation: Current knowledge and future directions. Sci Total Environ 2014; 472: 642-53.

[43] Bais HP, Weir TL, Perry LG, Gilroy S, Vivanco JM. The role of root exudates in rhizosphere interactions with plants and other organisms. Annu Rev Plant Biol 2006; 57: 233-66.

[44] Kumar R, Pandey S, Pandey A. Plant roots and carbon sequestration. Curr Sci 2006; 91: 885-90.

[45] Chen SH, Aitken MD. Salicylate stimulates the degradation of high molecular weight polycyclic aromatic hydrocarbons by Pseudomonas saccharophila p15. Environ Sci Technol 1999; 33: 435-9.

[46] Master ER, Mohn WW. Induction of $b p h A$, encoding biphenyl dioxygenase, in two polychlorinated biphenyl-degrading bacteria, psychrotolerant Pseudomonas strain cam-1 and mesophilic Burkholderia strain lb400. Appl Environ Microbiol 2001; 67: 2669-76.

[47] Singer AC, Gilbert ES, Luepromchai E, Crowley DE. Bioremediation of polychlorinated biphenyl-contaminated soil using carvone and surfactant-grown bacteria. Appl Microbiol Biotechnol 2000; 54: 838-43.

[48] Kim D, Park MJ, Koh SC, So JS, Kim E. Three separate pathways for the initial oxidation of limonene, biphenyl, and phenol by Rhodococcus sp strain t104. J Microbiol 2002; 40: 86-9.

[49] Hyman MR, Russell SA, Ely RL, Williamson KJ, Arp DJ. Inhibition, inactivation, and recovery of ammonia-oxidizing activity in cometabolism of trichloroethylene by Nitrosomonas europaea. Appl Environ Microb 1995; 61(4): 1480-7.

[50] Schwitzguébel JP, Aubert S, Grosse W, Laturnus F. Sulphonated aromatic pollutants: Limits of microbial degradability and potential of phytoremediation. Environ Sci Pollut Res 2002; 9(1): 62-72.

[51] Wenzel WW. Rhizosphere processes and management in plantassisted bioremediation (phytoremediation) of soils. Plant Soil 2008; 321(1-2): 385-408.

[52] Dams RI, Paton GI, Killham K. Rhizoremediation of pentachlorophenol by Sphingobium chlorophenolicum ATCC 39723. Chemosphere 2007; 68(5): 864-70.

[53] Gunderson JJ, Knight JD, Van Rees KCJ. Impact of ectomycorrhizal colonization of hybrid poplar on the remediation of diesel-contaminated soil. J Environ Qual 2007; 36(4): 927-34.

[54] Lodewyckx C, Vangronsveld J, Porteous F, et al. Endophytic bacteria and their potential applications. Crit Rev Plant Sci 2002; 21: 583-606.

[55] Moore FP, Barac T, Borrernans B, et al. Endophytic bacterial diversity in poplar trees growing on a BTEX-contaminated site: The characterisation of isolates with potential to enhance phytoremediation. Syst Appl Microbiol 2006; 29: 539-56.

[56] Yrjala K, Mancano G, Fortelius C, Akerman ML, Sipila TP. The incidence of Burkholderia in epiphytic and endophytic bacterial cenoses in hybrid aspen grown on sandy peat. Boreal Environ Res 2010; 15: 81-96.

[57] Berg G, Krechel A, Ditz M, Sikora RA, Ulrich A, Hallmann J. Endophytic and ectophytic potato-associated bacterial communities differ in structure and antagonistic function against plant pathogenic fungi. FEMS Microbiol Ecol 2005; 51: 215-29.

[58] Ryan RP, Germaine K, Franks A, Ryan DJ, Dowling DN. Bacterial endophytes: Recent developments and applications. FEMS Microbiol Lett 2008; 278: 1-9.
[59] Doty SL. Enhancing phytoremediation through the use of transgenics and endophytes. New Phytol 2008; 179: 318-33.

[60] McGuinness M, Dowling D. Plant-associated bacterial degradation of toxic organic compounds in soil. Int J Environ Res Public Health 2009; 6: 2226-47.

[61] Barac T, Taghavi S, Borremans B, et al. Engineered endophytic bacteria improve phytoremediation of water-soluble, volatile, organic pollutants. Nat Biotechnol 2004; 22: 583-8.

[62] Germaine KJ, Liu X, Cabellos GG, Hogan JP, Ryan D, Dowling DN. Bacterial endophyte-enhanced phytoremediation of the organochlorine herbicide 2,4-dichlorophenoxyacetic acid. FEMS Microbiol Ecol 2006; 57: 302-10.

[63] Phillips LA, Germida JJ, Farrell RE, Greer CW. Hydrocarbon degradation potential and activity of endophytic bacteria associated with prairie plants. Soil Biol Biochem 2008; 40: 3054-64.

[64] Phillips LA, Greer CW, Farrell RE, Germida JJ. Field-scale assessment of weathered hydrocarbon degradation by mixed and single plant treatments. Appl Soil Ecol 2009; 42: 9-17.

[65] Taghavi S, Barac T, Greenberg B, Borremans B, Vangronsveld J, van der Lelie D. Horizontal gene transfer to endogenous endophytic bacteria from poplar improves phytoremediation of toluene. Appl Environ Microbiol 2005; 71: 8500-5.

[66] Wang Y, Xiao M, Geng X, Liu J, Chen J. Horizontal transfer of genetic determinants for degradation of phenol between the bacteria living in plant and its rhizosphere. Appl Microbiol Biotechnol 2007; 77: 733-9.

[67] Afzal M, Khan QM, Sessitsch A. Endophytic bacteria: Prospects and applications for the phytoremediation of organic pollutants. Chemosphere 2014; 117: 232-42.

[68] Nedunuri KV, Govindaraju RS, Banks MK, Schwab AP, Chen Z. Evaluation of phytoremediation for field-scale degradation of total petroleum hydrocarbons. J Environ Eng 2000; 126(6): 483-90.

[69] Azaizeh H, Castro PML, Kidd P. Biodegradation of Organic Xenobiotic Pollutants in the Rhizosphere. In: Schröder P, Collins CD, Eds. Organic Xenobiotics and Plants, Springer Netherlands, Dordrecht 2011; 191-215.

[70] Siciliano SD, Germida JJ, Banks K, Greer CW. Changes in microbial community composition and function during a polyaromatic hydrocarbon phytoremediation field trial. Appl Environ Microb 2003; 69(1): 483-9.

[71] Robinson SL, Novak JT, Widdowson MA, Crosswell SB, Fetterolf GJ. Field and laboratory evaluation of the impact of tall fescue on polyaromatic hydrocarbon degradation in an aged creosotecontaminated surface soil. J Environ Eng 2003; 129(3): 232-40.

[72] White Jr PM, Wolf DC, Thoma GJ, Reynolds CM. Phytoremediation of alkylated polycyclic aromatic hydrocarbons in a crude oil-contaminated soil. Water Air Soil Poll 2006; 169(1-4): 207-20.

[73] van Dillewijn P, Caballero A, Paz JA, González-Pérez MM, Oliva JM, Ramos JL. Bioremediation of 2,4,6-trinitrotoluene under field conditions. Environ Sci Technol 2007; 41(4): 1378-83.

[74] Barac T, Weyens N, Oeyen L, et al. Field note: Hydraulic containment of a BTEX plume using poplar trees. Int $\mathbf{J}$ Phytoremediat 2009; 1(5): 416-24.

[75] Weyens $\mathrm{N}$, van der Lelie D, Taghavi S, Vangronsveld J. Phytoremediation: plant-endophyte partnerships take the challenge. Curr Opin Biotechnol 2009; 20(2): 248-54.

[76] Weyens N, van der Lelie D, Artois T, et al. Bioaugmentation with engineered endophytic bacteria improves contaminant fate in phytoremediation. Environ Sci Technol 2009; 43(24): 9413-8.

[77] Braeckevelt M, Rokadia H, Imfeld G, et al. Assessment of in situ biodegradation of monochlorobenzene in contaminated groundwater treated in a constructed wetland. Environ Pollut 2007; 148: 428-37.

[78] Calheiros CSC, Rangel A, Castro PML. Constructed wetland systems vegetated with different plants applied to the treatment of tannery wastewater. Water Res 2007; 41: 1790-8.

[79] Calheiros CSC, Teixeira A, Pires C, et al. Bacterial community dynamics in horizontal flow constructed wetlands with different plants for high salinity industrial wastewater polishing. Water Res 2010; 44(17): 5032-8.

[80] Matamoros V, Mujeriego R, Bayona JM. Trihalomethane occurrence in chlorinated reclaimed water at full-scale wastewater treatment plants in NE Spain. Water Res 2007; 41: 3337-44.

[81] Vymazal J. Constructed wetlands for wastewater treatment: five decades of experience. Environ Sci Technol 2011; 45(1): 61-9. 
[82] Ligi T, Oopkaup K, Truu M, et al. Characterisation of bacterial communities in soil and sediment of a created riverine wetland complex using high-throughput 16S rRNA amplicon sequencing. Ecol Eng 2014; 72: 56-66.

[83] Mitsch WJ, Zhang L, Stefanik KC, et al. Creating wetlands: primary succession, water quality changes, and self-design over 15 years. BioScience 2012; 62(3): 237-50.

[84] Schröder P, Navarro-Aviñó J, Azaizeh $\mathrm{H}$, et al. Using phytoremediation technologies to upgrade waste water treatment in Europe. Environ Sci Pollut Res Int 2007; 14(7): 490-7.

[85] Hijosa-Valsero M, Fink G, Schlüsener MP, et al. Removal of antibiotics from urban wastewater by constructed wetland optimization. Chemosphere 2011; 83(5): 713-9.

[86] Imfeld G, Braeckevelt M, Kuschk P, Richnow HH. Monitoring and assessing processes of organic chemicals removal in constructed wetlands. Chemosphere 2009; 74(3): 349-62.

[87] Shelef O, Gross A, Rachmilevitch S. Role of plants in a constructed wetland: current and new perspectives. Water 2013; 5(2): 405-19.

[88] Zhang D, Gersberg RM, Ng WJ, Tan SK. Removal of pharmaceuticals and personal care products in aquatic plant-based systems: a review. Environ Pollut 2014; 184: 620-39.

[89] Truu M, Juhanson J, Truu J. Microbial biomass, activity and community composition in constructed wetlands. Sci Total Environ 2009; 407(13): 3958-71

[90] Verlicchi P, Zambello E. How efficient are constructed wetlands in removing pharmaceuticals from untreated and treated urban wastewaters? A review. Sci Total Environ 2014; 470-471: 1281306.

[91] Cardinal P, Anderson JC, Carlson JC, Low JE, Challis JK, Beattie SA, Wong CS. Macrophytes may not contribute significantly to removal of nutrients, pharmaceuticals, and antibiotic resistance in model surface constructed wetlands. Sci Total Environ 2014; 482483: 294-304.

[92] Elsaesser D, Blankenberg AGB, Geista A, Mæhlumb T, Schulz R. Assessing the influence of vegetation on reduction of pesticide concentration in experimental surface flow constructed wetlands: application of the toxic units approach. Ecol Eng 2011; 37: 955-62.

[93] Schulz R, Moore MT, Bennett ER, Farris JL, Smith Jr SS, Cooper CM. Methyl parathion toxicity in vegetated and nonvegetated wetland mesocosms. Environ Toxicol Chem 2003; 22: 1262-8.

[94] Braeckevelt M, Mirschel G, Wiessner A, et al. Treatment of chlorobenzene contaminated groundwater in a pilot-scale constructed wetland. Ecol Eng 2008; 33: 45-53.

[95] Braeckevelt M, Reiche N, Trapp S, et al. Chlorobenzene removal efficiencies and removal processes in a pilotscale constructed wetland treating contaminated groundwater. Ecol Eng 2011; 37: 903-13.

[96] Zhou Y, Trestip S, Li X, Truu M, Truu J, Mander Ü. Dechlorination of hexachlorobenzene in treatment microcosm wetlands. Ecol Eng 2012; 42: 249-55.

[97] Zhou Y, Tigane T, Li X, Truu M, Truu J, Mander Ü. Hexachlorobenzene dechlorination in constructed wetland mesocosms. Water Res 2012; 47(1): 102-10.

[98] Elsayed OF, Maillard E, Vuilleumier S, Imfeld G. Bacterial communities in batch and continuous-flow wetlands treating the herbicide S-metolachlor. Sci Total Environ 2014; 499: 327-35.

[99] Avila C, Reyes C, Bayona JM, García J. Emerging organic contaminant removal depending on primary treatment and operational strategy in horizontal subsurface flow constructed wetlands: influence of redox. Water Res 2014; 47: 315-25.

[100] Zhang DQ, Gersberg RM, Zhu J, Hua T, Jinadasa KBSN, Tan SK. Batch versus continuous feeding strategies for pharmaceutical removal by subsurface flow constructed wetland. Environ Pollut 2012; 167: 124-31.

[101] Calheiros CSC, Rangel AOSS, Castro PML. The effects of tannery wastewater on the development of different plant species and chromium accumulation in Phragmites australis. Arch Environ Contam Toxicol 2008; 55(3): 404-14.

[102] Calheiros CSC, Rangel AOSS, Castro PML. Potential of constructed wetland phytotechnology for tannery wastewater treatment. In: Anjum NA, Pereira ME, Ahmad I, Duarte AC, Umar S, Khan NA, Eds. Phytotechnologies: remediation of environmental contaminants. CRC Press, Florida 2012; pp. 83-98.

[103] Sukumaran D. Phytoremediation of heavy metals from industrial effluent using constructed wetland technology. Appl Ecol Environ Sci 2013; 1(5): 92-7.

[104] Madera-Parra CA, Peña-Salamanca EJ, Peña MR, Rousseau DPL Lens PNL. Phytoremediation of landfill leachate with Colocasia esculenta, Gynerum sagittatum and Heliconia psittacorum in constructed wetlands. Int J Phytoremediat 2015; 17: 16-24.

[105] Anning AK, Korsah PE, Addo-Fordjour P. Phytoremediation of wastewater with limnocharis flava, thalia geniculata and typha latifolia in constructed wetlands. Int J Phytoremediat 2013; 15(5): 452-64.

[106] Huguenot D, Bois P, Cornu JY, Jezequel K, Lollier M, Lebeau T. Remediation of sediment and water contaminated by copper in small-scaled constructed wetlands: effect of bioaugmentation and phytoextraction. Environ Sci Pol Res 2014; 22: 721-32.

(C) Truu et al.; Licensee Bentham Open.

This is an open access article licensed under the terms of the Creative Commons Attribution Non-Commercial License (http://creativecommons.org/licenses/by-nc/3.0/) which permits unrestricted, non-commercial use, distribution and reproduction in any medium, provided the work is properly cited. 